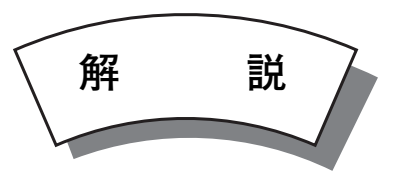

\title{
高出力半導体レーザによる微細接合技術に関する研究
}

\section{A Study of Micro Welding with High Power Direct Diode Laser}

\author{
舟田義則**阿部信行**・塚本雅 裕***村谷外博*** \\ Yoshinori FUNADA, Nobuyuki ABE, Masahiro TSUKAMOTO and Sotohiro MURATANI
}

Key Words: Direct Diode Laser, Micro Welding, Air Cooled, Fiber Coupled Laser Diode

\section{1. 緒言}

電気電子産業や精密機械産業では、工業製品の多機能化 や省力化に対応するため、使用部材の微細化や薄肉化が求 められ、それに対応した超薄板の溶接技術の確立が望まれ ている。超薄板を溶接する場合、溶け落ちなどが生じやす く、溶接における入熱の量や領域を精密に制御する必要が ある。これには、レーザ溶接が有効である。アーク溶接に 比べて入熱範囲を狭くでき、その量を精密に制御できるか らである。

レーザ溶接に広く利用されているレーザ発振器として $\mathrm{Nd}$ ：YAG レーザがある ${ }^{1)}$ 。レーザ光の波長が $1.06 \mu \mathrm{m}$ と近 赤外領域であり、その伝送に光ファイバを使用できること から、集光へッドを溶接部材に応じて自由に配置可能であ る。また、金属材料に対する吸収率が $\mathrm{CO}_{2}$ レーザに比べて 高く、溶接部を効率良く加熱できる特徴がある。しかしな がら、電気 - 光変換効率が数 \% と低いため、レーザ光の発 振に多量の電力を消費する。また、励起ランプなど消耗品 も高価であることからランニングコストが高い。さらに、、 イニシャルコストが高く、維持管理が煩雑であるため、そ の利用は大企業や一部の中小企業に限られている。

これを解決する次世代レーザ装置の 1 つとして高出力半 導体レーザがある ${ }^{2}$ 。レーザダイオード(LD)のエミッタ から発振されるレーザ光を直接利用するレーザ装置である が、これまで、エミッタ 1 つ当たりのレーザ光出力は低く、 そのままでは材料加工には使用できなかった。そこで、工 ミッタを横方向に数十個集積した LD アレイバー技術や、 さらにそれを複数個積載した LD スタック技術が開発され、 最大数 $\mathrm{kW}$ までの高出力化が達成されている。その電気一 光変換効率は最大で $50 \%$ あり、 $\mathrm{Nd}$ ：YAG レーザより十倍 以上高い。また、定期交換が必要な消耗品がなくメンテナ
ンスフリーで 10,000 時間以上使用することが可能である。 半田付けや樹脂溶着 ${ }^{3)}$ 、表面処理 ${ }^{4)}$ の分野では既に実用化 されている。

高出力半導体レーザでは、レーザ光の拡がり方（発散角） が方向によって異なり、レーザ光を微細な円に集光するこ とは困難であるため精密加工に利用されることはほとんど なかった。しかしながら、拡がりに異方性のあるレーザ光 では、細長い楕円に集光することは比較的容易である。楕 円に集光したレーザ光をその長径方向に走査すれば、幅方 向への加熱を抑えながら溶接方向に高効率で加熱できると 考えられる。これを利用すれば、高出力半導体レーザの超 薄板精密溶接への適用が期待できる ${ }^{5,6)}$ 。

一方、高出力半導体レーザにて安定した出力のレーザ光 を得るためには、レーザ光発振時の LD アレイバーやスタッ クの温度上昇を防ぐための冷却が必要である。エミッタが 高密度に集積されているため空冷は難しく、通常はマイク 口流路による水冷が行われている。しかしながら、水詰 まりによるオーバーヒートを起こしやすく、故障の原因に なっている7。これに変わるものとして、エミッ夕 1 つ当 たりの出力が従来に比べて数倍高く、さらに、伝送用光ファ イバが直接に接続されたファイバ結合 LD 素子が注目され ている ${ }^{8)}$ 。ファイバレーザ用の励起光源として開発された 素子であり、装置化した場合の冷却が比較容易であるため 空冷化が期待できる。

以上のことから、著者らは、高出力半導体レーザを利用

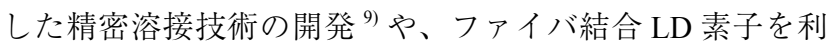
用した半導体レーザ装置およびこれを搭載した加工機の開 発を行っており、その内容を紹介する。

\section{2. 高出力半導体レーザによる精密溶接}

Fig. 1 に波長が $808 \mathrm{~nm}$ のレーザ光を $\mathrm{CW}$ 発振する LD ス

*石川県工業試験場 機械金属部（９ 920-8203 石川県金沢市鞍月 2-1）

Industrial Research Institute of Ishikawa, Machinery/Metal Department (2-1 Kuratsuki, Kanazawa, Ishikawa, 920-8203 Japan)

**大阪大学接合科学研究所 ( $\overline{\mathrm{T}}$ 567-0047 大阪府茨木市美穂ヶ丘 11-1)

Joining and Welding Research Institute, Osaka University (11-1 Mihogaoka, Ibaraki, Osaka, 567-0047 Japan)

***株式会社村谷機械製作所（９ 920-0209 石川県金沢市東蚊爪町 1 -32）

Muratani machine Incorporated. (1-32, Higashi-kagatsume, Kanazawa, Ishikawa, 920-0209 Japan) 


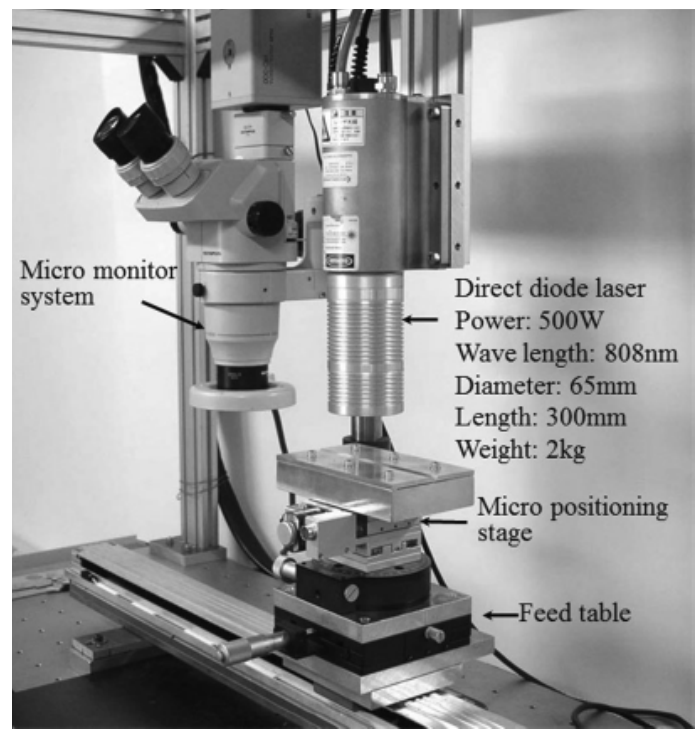

Fig .1 high power direct diode laser

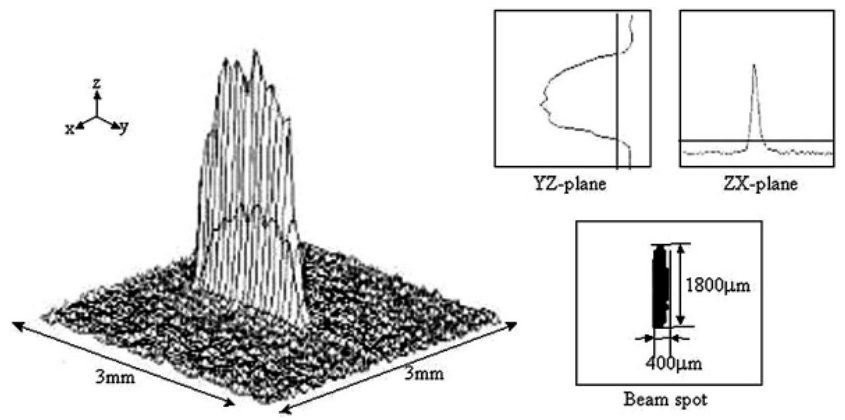

Fig. 2 Beam profile

タック型の高出力半導体レーザ装置を示す。最大で $500 \mathrm{~W}$ のレーザ光を照射可能でありながら、そのサイズは $\phi 65$ $\mathrm{mm} \times \mathrm{L} 300 \mathrm{~mm}$ と小型である。Fig. 2 は焦点距離 $50 \mathrm{~mm}$ の 位置における集光形状をビームプロファイラで測定した結 果であり、 $2 \mathrm{~mm} \times 0.4 \mathrm{~mm}$ の楕円である。この装置を用い て厚さ $0.1 \mathrm{~mm}$ のステンレス鋼超薄板の突き合わせ溶接実 験を行った結果を Fig. 3 に示す。このときの出力は $300 \mathrm{~W}$

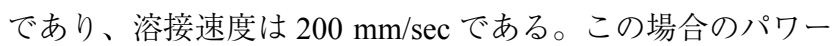
密度は $48 \mathrm{~kW} / \mathrm{cm}^{2}$ と低いにも関わらず、楕円状に集光した レーザ光をその長径方向に走査することによって部材を歪 ませることなく貫通溶接することができた。

この要因として、レーザ光の楕円状集光による溶接方向 への入熱の高効率化が考えられる。そこで、厚さが $0.1 \mathrm{~mm}$ のステンレス鋼超薄板について溶接時の温度分布を熱伝導 解析によって調べた。板材表面中央を長手方向にレーザ光 が移動して溶接する場合、解析の対象となる部材は光軸を 中心とした線対称であることから、その片側だけを計算す
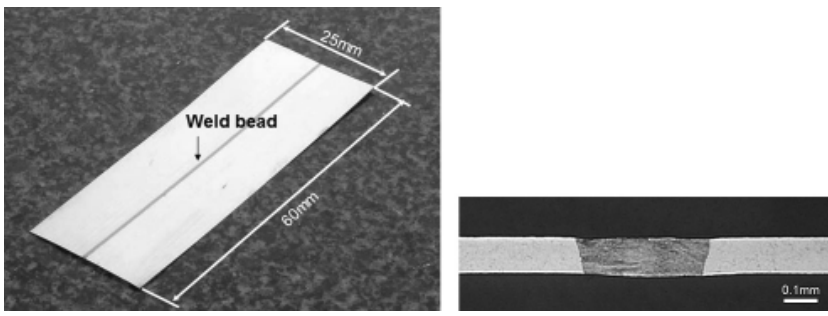

Fig. 3 Appearance and cross section of a welded stainless steel sheet in thickness of $0.1 \mathrm{~mm}$.

\section{Circular beam}

\section{Elliptical beam}

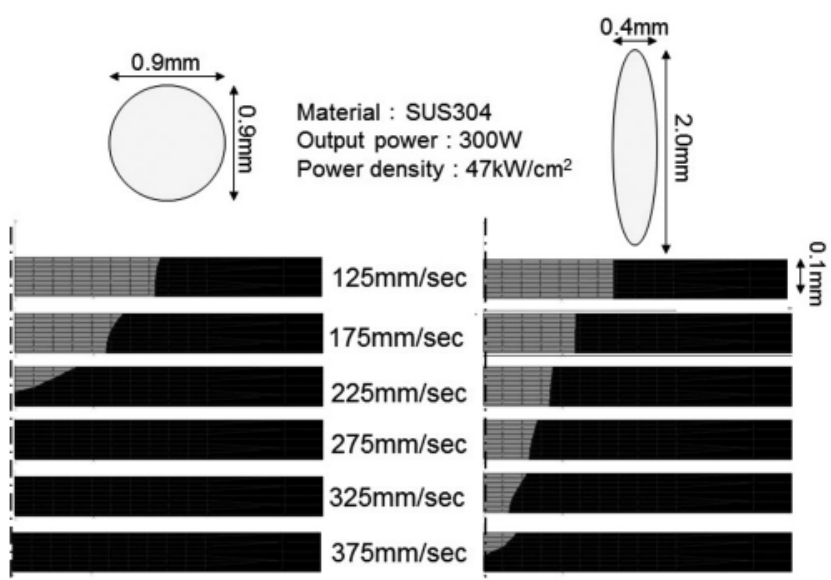

Fig. 4 Results of thermal conductive analysis on temperature distributions during welding.

れば十分であり、解析には $1 / 2$ モデルを用いた。Fig. 4 は 溶接方向に直角な断面について、温度が融点 $(1700 \mathrm{~K})$ を超 える領域を、集光形状が $2 \mathrm{~mm} \times 0.4 \mathrm{~mm}$ の楕円状の場合と 投影面積が同じで集光形状が $\phi 0.9 \mathrm{~mm}$ の円の場合とで比 較して示した結果である。レーザ光出力およびパワー密度 は $300 \mathrm{~W} 、 48 \mathrm{~kW} / \mathrm{cm}^{2}$ と同じ条件でありながら、集光形状 が楕円である方が、より高速で貫通溶接が可能であり、ま た、溶け込み幅を狭くできる。集光形状を楕円とすること で、溶接方向に高効率に入熱でき、高速で溶け込み幅が狭 い超薄板の精密溶接が可能であることが示された。

\section{3. 高出力半導体レーザによる精密溶接機の開発}

高出力半導体レーザによる精密溶接技術を実用化するた め、全 6 軸からなる多軸位置決め装置と高出力半導体レー ザを組み合わせた精密溶接機を製作した。Fig. 5 はその概 観である。部材の $\mathrm{X}$ 軸、Y 軸、 $\mathrm{Z}$ 軸方向への直線移動に加 えて $\theta$ 軸の回転移動が可能である。これに、CW 発振で最 大出力が $200 \mathrm{~W}$ 、発振波長が $808 \mathrm{~nm} 、 50 \mathrm{~mm}$ 離れた焦点位 置での集光形状が $2 \mathrm{~mm} \times 0.2 \mathrm{~mm}$ の楕円である LD スタッ ク型高出力半導体レーザを搭載し、A 軸による傾斜と $\mathrm{C}$ 軸 

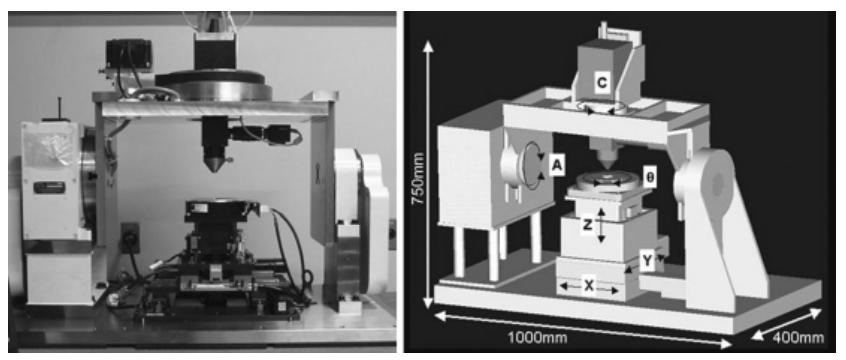

Fig. 5 Appearance and schematic diagram of a fine welding apparatus quipped with a high power direct diode laser and a multi axis positioner.
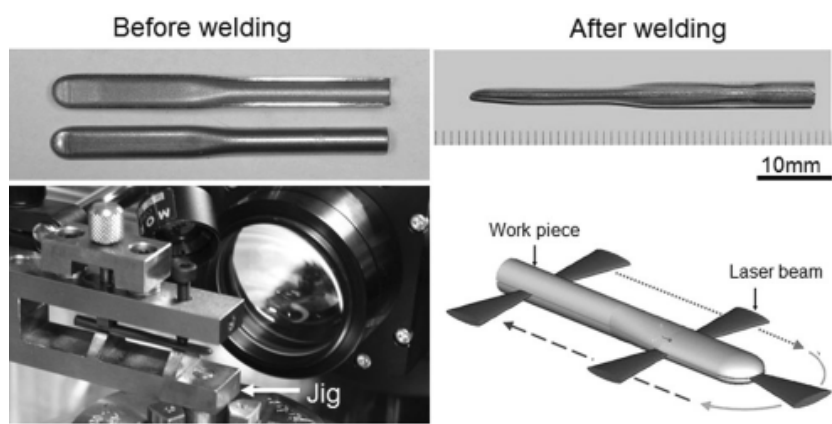

Fig. 6 Half cut parts welded with a fine welding apparatus.

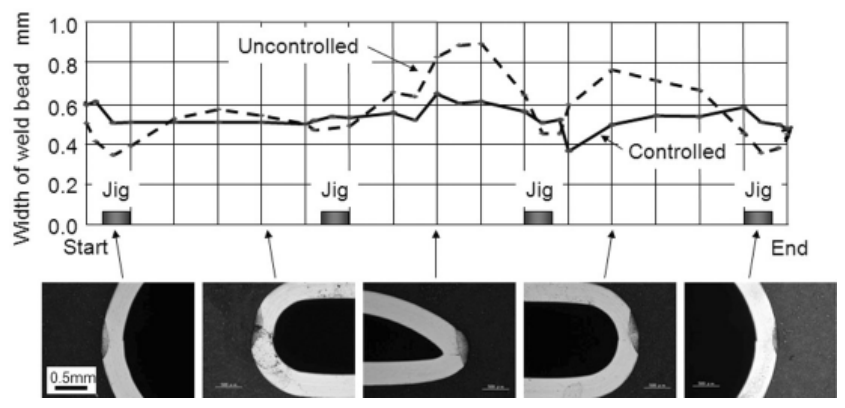

Fig. 7 Width of weld beads at each regions of half cut parts with and without controlling laser output power.

による回転を可能とした。さらに、位置決め装置と同期し てレーザ光出力を変動させる機能を付与した。

同装置を用いて、Fig. 6 に示す半割部品を2つ重ねて全 周溶接した。Fig. 7 は、溶接部品の各位置に扔ける溶け込 み幅を測定し、展開表示した結果である。出力が一定の場 合、溶け込み幅はジグ接触部で狭くなり、先端部分で広く なる。また、「行き」に比べて「帰り」の方が溶け込み幅 は広くなる。熱拡散が各位置によって異なることがその原 因と考光られる。そこで、熱拡散が大きい位置では出力を 上げ、逆に熱拡散が小さい位置では出力を下げるような出 力制御パターンを作成し、これを基に位置決めと同期して

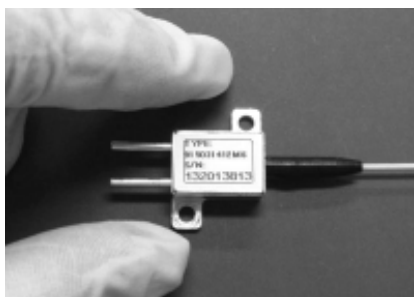

(a) Laser diode

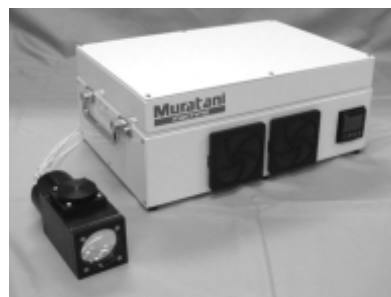

(b) High power diode laser
Fig. 8 Appearances of a fiber coupled laser diode and air cooled high power direct diode laser utilizing it.

レーザ光出力を変動させた。その結果、溶け込み幅のばら つきを $0.6 \mathrm{~mm}$ から $0.25 \mathrm{~mm}$ まで低減でき、出力制御が溶 け込み幅の均一化に有効であることがわかった。以上のこ とから、適用がほとんどなかった精密溶接の分野にも高出 力半導体レーザは十分使用可能であることが示された。

\section{4. ファイバ結合 LD 素子を用いたレーザ装置の開発}

LD スタック型の高出力半導体レーザはマイクロ流路に 水を流すことで冷却しながら使用される。その冷却水管が 様々な原因で水詰まりを発生し、LD 素子のオーバーヒー トによる故障が問題視されている。そこで、LDスタック 型に変わる空冷式の高出力半導体レーザの開発を行った。

Fig. 8(a)は、装置開発に利用したファイバ結合 LD 素子 であり、1 個当たり $10 \mathrm{~W}$ 以上の出力が可能である。これ を必要な数だけ搭載し、各々から発振されるレーザ光を集 光して照射可能な専用の加工へッドを備えた高出力半導体 レーザを開発した。同図 (b) は発振波長が $915 \mathrm{~nm}$ で最大出 力が $150 \mathrm{~W}$ の空冷式高出力半導体レーザである。この装置 では、LD 素子を個別に冷却できるため、空冷化が容易で ある他、構造が簡便なため故障した場合も短時間で修理可 能である。

また、専用の加工ヘッドには、LD 素子からのレーザ光 を伝送する複数の光ファイバが束ねて組み込まれている。 その組み込み方を変えることによって、光ファイバに対応 する各集光点を自由に配置でき、焦点位置での集光形状を 変更できる。Fig. 9 はその例であり、光ファイバを直線状 に束ねた加工へッドを用意すれば、各光ファイバに対応す る集光点は直線的に並べられ、集光形状は直線となる。ま た、各集光点を全て同一点上に重ねることができる加工 ヘッドに交換化すれば、レーザ光を点状に集光することが 可能となる。また、各集光点の配置を、交換することなく 1 台で自由に調整可能な加工ヘッドを開発した。

溶接の際のレーザ加熱では、これまでレーザ光を一点に 集光して利用することがほとんどであった。これに対して、 部材形状や接合方法に応じて集光形状を自由に設定できる ようなり、このことは溶接品質と生産性の向上に大きく貢 


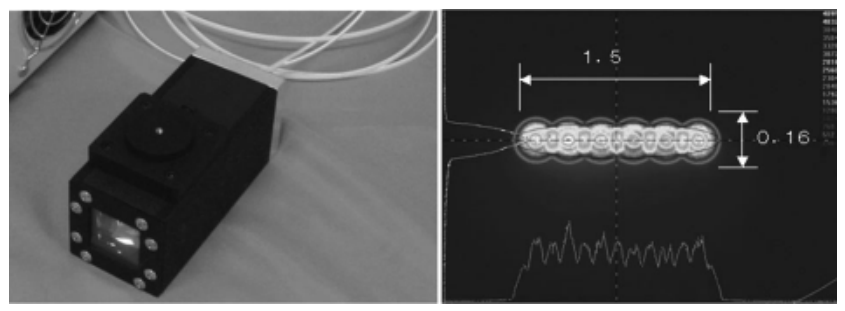

(a) Line pattern head
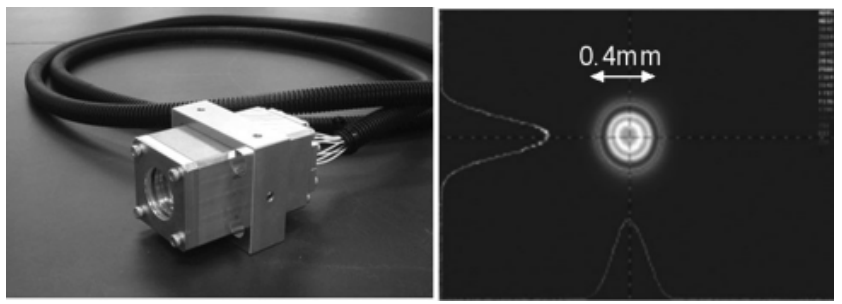

(b) Point pattern head
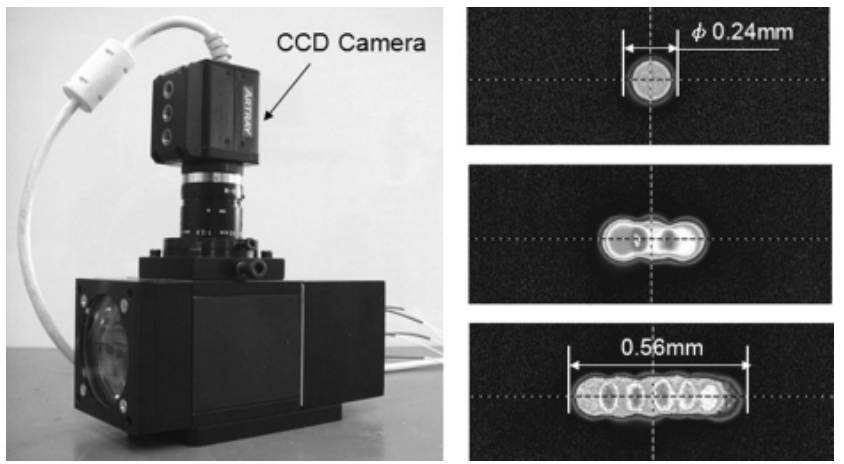

(c) Adjustable pattern head

Fig. 9 Several types of Laser head connected with an air cooled high power direct diode laser.

献できると考えられる。

\section{5. レーザ接合専用機への応用}

\section{1 レーザ精密溶接機}

Fig. 10 は、電子部品向けに専用に開発したレーザ精密溶 接機である。これは、Fig. 11 に示すように内外径がそれぞ れ $\phi 10 \mathrm{~mm}$ と $\phi 12 \mathrm{~mm}$ の円管部材を上下に積み重ね、そ の間に厚さ $0.1 \mathrm{~mm}$ の超薄板を挿入し、その部分を全周溶 接するための装置である。最大出力 $150 \mathrm{~W}$ の空冷式高出力 半導体レーザを $\mathrm{V}$ 字に 2 台搭載し、合計 $300 \mathrm{~W}$ のレーザ光 出力で溶接が可能である。これに組み合わせたのは一点集 光型の加工ヘッドであり、90 $\mathrm{mm}$ 離れた焦点位置において レーザ光を $\phi 0.25 \mathrm{~mm}$ まで集光可能である。溶接部材を機 械内に供給すると、専用ジグにより位置合わせと把持が自 動で行われる。そして、固定された溶接部材を一定速度で 回転させながら側面方向からレーザ光を照射することで、

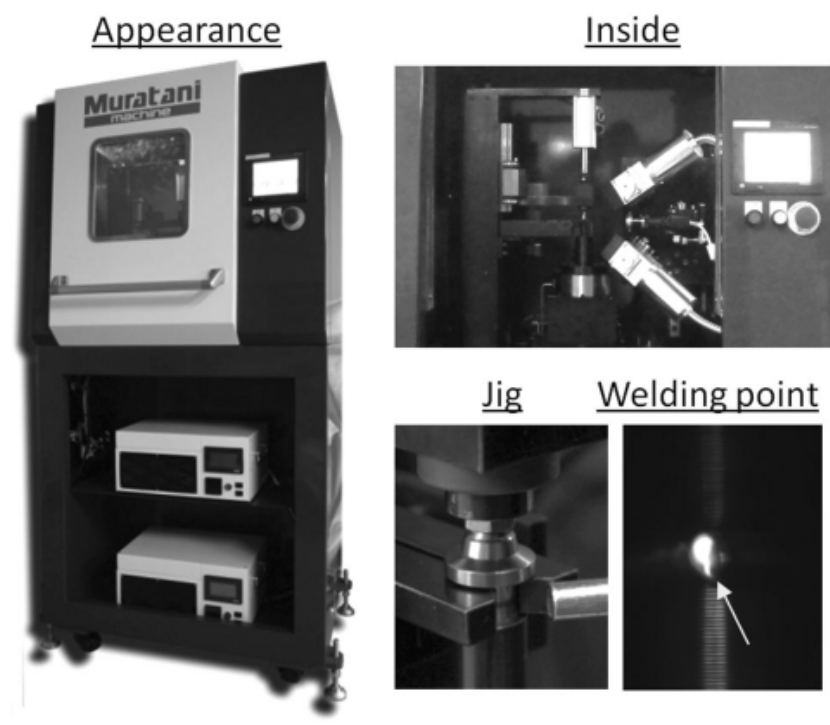

Fig. 10 A fine welding apparatus equipped with two air cooled high power direct diode laser.

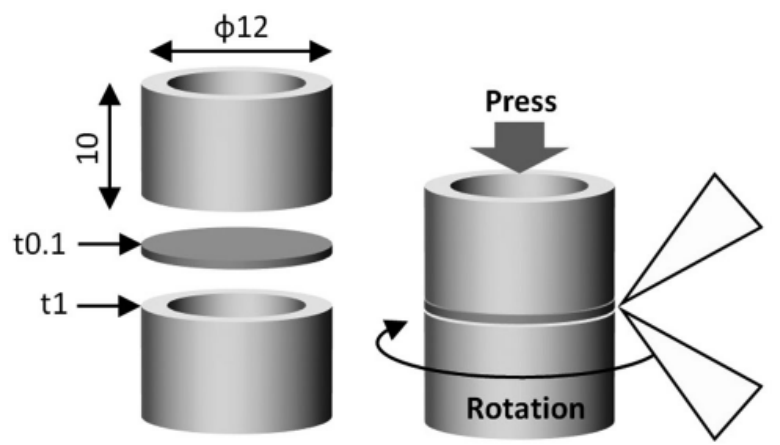

Fig. 11 Schematic diagram of welded parts consisting of metallic pipes and a sheet in thickness of $0.1 \mathrm{~mm}$.

溶接が行われる。

Fig. 12(a) は、合計出力が $220 \mathrm{~W}$ 、溶接速度が周速で 10 $\mathrm{mm} / \mathrm{sec}$ の条件でステンレス鋼 (SUS304) 製の部材を溶接し たときの外観である。溶接中は不活性ガス（アルゴンガス） でシールドしているため、溶接部は変色せず、高品位な溶 接が実現できている。同図 (b) は、溶接部部材のカットサ ンプル全体像と溶接部断面を拡大観察したものである。溶 け込みは表面より $0.3 \mathrm{~mm}$ 程度まで到達し、また、3 部材間 を確実に接合できている。また、溶け込み内部には空隙や 割れは見られず、健全な溶接が行われていることが確認で きる。

実製品を半自動で溶接可能としながら、溶接機のサイズ はW $800 \mathrm{~mm} \times \mathrm{D} 800 \mathrm{~mm} \times \mathrm{H} 1800 \mathrm{~mm}$ とコンパクトである。 この中には、レーザ用駆動電源など必要な機材は含まれて おり、従来の $\mathrm{Nd}$ ：YAG レーザ溶接機と比較して大幅に小 


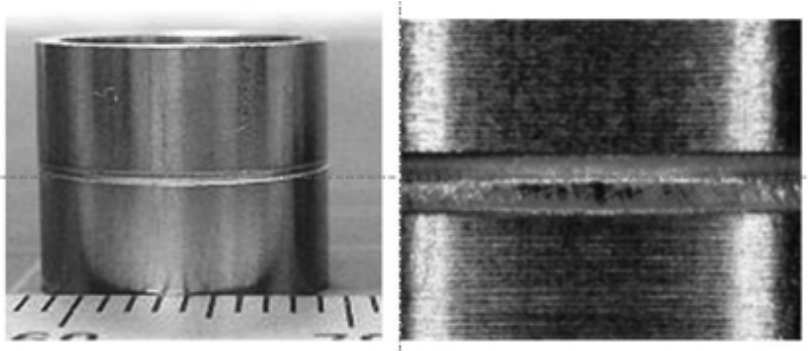

(a) Appearance

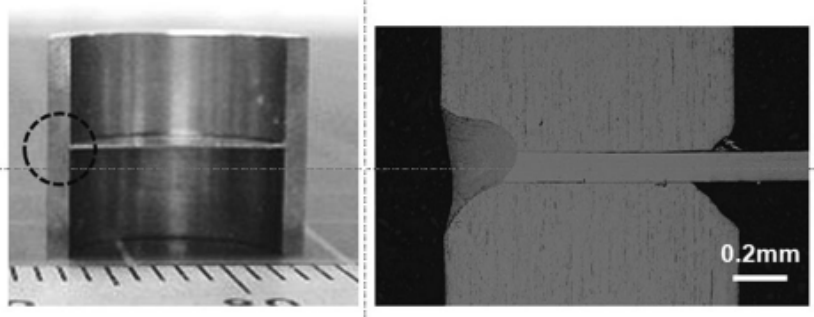

(b) Cross section

Fig. 12 Appearance and cross section of welded parts with the fine welding apparatus.

型化されている。

\section{2 マルチビーム式レーザろう付機}

微細な部材をろう付する場合、高周波による局部加熱で あっても入熱範囲が広くなり過ぎ、周辺に及ぼす熱影響が 許容できなくなる。そこで、Fig. 13 に示す小径ピン用に開 発したマルチビーム式レーザろう付機を開発した。これに は、最大出力 $60 \mathrm{~W}$ の空冷式高出力半導体レーザを 4 台搭 載し、それぞれに、Fig. 14 に示すように集光点を直線的に 配置することによって集光形状を直線とする加工へッドを 組み合わせた。ピン材を中心にこれらを等間隔で設置し、 全加工ヘッドからレーザ光を同時に照射することによって $\phi 1.5 \mathrm{~mm}$ 程度までの小径ピンを回転させることなく全周 加熱することを可能にした。部材を回転させて行う従来の レーザろう付と比べて、接合精度の向上や接合時間の短縮、 加熱に必要なレーザ光出力の低減が期待できる。

Fig. 15 は、マルチビーム式レーザろう付機を用いて $\phi$ $1.5 \mathrm{~mm}$ の超硬ピンとステンレス鋼ピンの異材ろう付を行っ た結果である。厚さ $0.1 \mathrm{~mm}$ の銀ろう材を用い、1 台当たり $40 \mathrm{~W}$ 、合計 $160 \mathrm{~W}$ のレーザ光を $2 \mathrm{sec}$ 間照射した結果、変 色や変形が全く見られないろう付が可能であった。接合精 度を測定した結果、芯ずれは $0.01 \mathrm{~mm}$ 以下であった。また、 せん断接合強度は使用したろう材のカタログ值とほぼ同じ であり、接合部に隙間など欠陥はないものと考えられる。 短時間のろう付で高精度かつ高品質な異材接合が可能とな り、本装置の有用性を示すことができた。

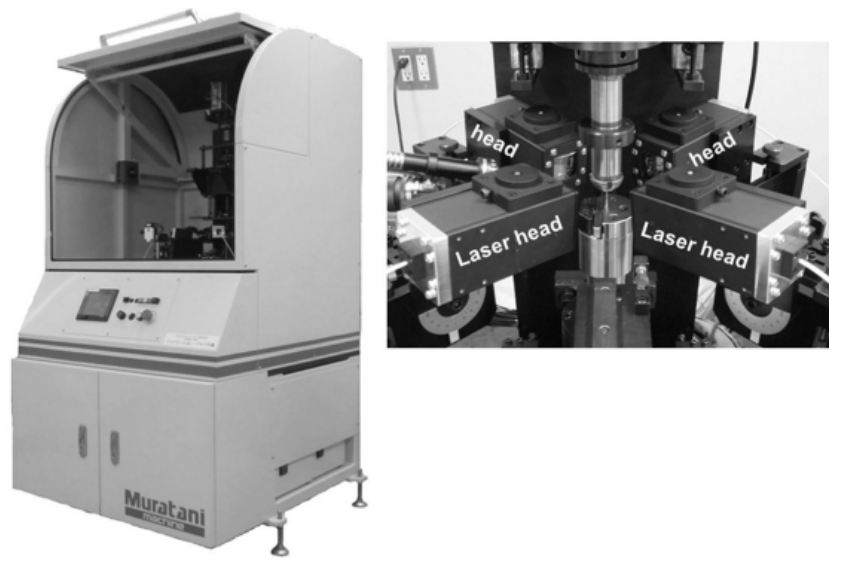

Fig. 13 A multi beam laser brazing apparatus equipped with four air cooled high power direct diode lasers.
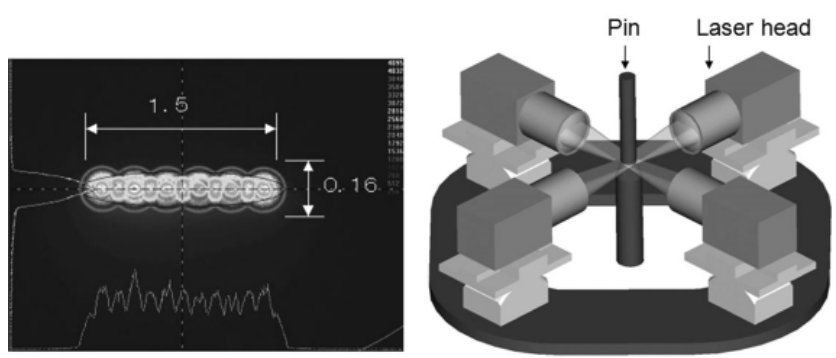

Fig. 14 A laser spot taking a shape of line pattern and a schematic diagram of multi beam laser brazing for micro pin parts without a rotation.

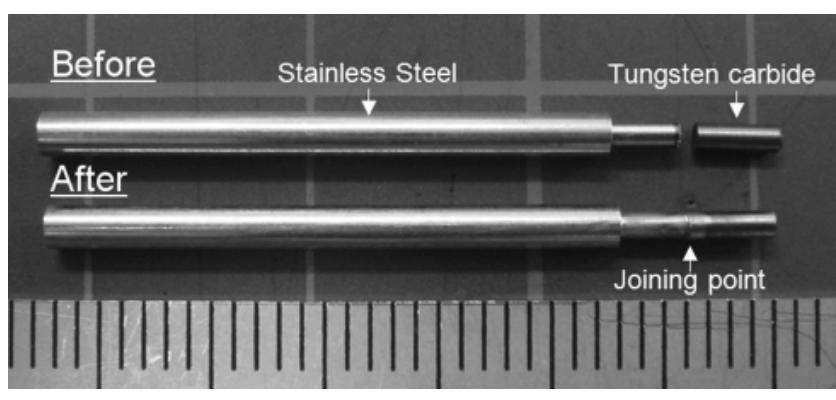

Fig. 15 Dissimilar brazing of micro stainless steel and tungsten carbide pins.

\section{6. 結 言}

本解説では、これまで精密加工の分野でほとんど使用さ れなかった高出力半導体レーザを用いて超薄板の精密溶接 が可能であることを示した。さらに、ファイバ結合 LD 素 子を利用した空冷式の高出力半導体レーザを開発すること によって、従来の溶接用レーザ装置に比べて使いやすく、 イニシャルコストの安いレーザ溶接機を実現した。これま 


$$
\text { スマートプロセス学会誌 第 } 1 \text { 巻 第 } 6 \text { 号（2012 年 } 11 \text { 月） }
$$

で導入を躊躇していた中小企業にレーザ溶接を広く普及す る機会の 1 つになることを期待している。

また、同装置は、溶接部材や溶接方法に応じて最大出力 や集光形状を様々に調整して製作することができる。これ までのレーザ機器のように 1 台で多くのことを行う汎用的 な使い方よりも、部材や工法に応じて専用機化して使用す ることの方が有用な装置である。これと組み合わせるジグ や自動機を工夫することによって他にはない高生産性と高 品質、低コストを両立した装置となり、差別化を図ったも のづくり技術の獲得に貢献できると期待している。

\section{引用文献}

1) オプトロニクス社編集部編：“実用レーザ加工応用ハンドブッ ク”、オプトロニクス社 (2000)22-26.

2) 阿部信行：レーザ加工学会誌、9-1 (2002) 7-12.
3) 三瓶和久：レーザ加工学会誌、14-4 (2007) 1-5.

4) 萩野秀樹、宮田良雄：大阪府立産業技術総合研究所報告、22 (2008) 33-38.

5) Y. Funada and N. Abe: Proc. of 22nd Internatinal Congress on Applications of Lasers \& Electro-optics (ICALEO 2003), 2003, M203.

6) Y. Funada and N. Abe: Proc. of 23rd Internatinal Congress on Applications of Lasers \& Electro-optics (ICALEO 2004), 2004, M702.

7) Georg Treusch, Raman Srinivasan, Dennis Brown, Robert Miller, Jim Harrison: Proc. SPIE, 5711 (2005) 132-141.

8) 藤本毅、山形友二、山田由美、斉藤剛、片平学、内田和臣：レー ザー学会誌、39-9 (2011) 674-679.

9) 阿部信行、舟田義則：電気学会論文誌 C、128-5 (2008) 703706. 